\title{
Effect of the application of stem cells for tendon injuries in sporting horses ${ }^{\#}$
}

\author{
Efecto de la aplicación de células madre en lesiones tendinosas de equinos deportivos
}

\author{
C Tuemmers*, N Rebolledo, R Aguilera
}

Universidad Católica de Temuco, Temuco, Chile.

\begin{abstract}
RESUMEN
La solución para las tendinitis sufridas por los equinos deportivos ha sido, por años, el dilema de los médicos veterinarios que se dedican a tratar este tipo de lesiones. La medicina regenerativa, utilizando células madre del mismo paciente, surge como un método innovador que permite atravesar la barrera de resolución mantenida en el tiempo y con ventajas que superan a las terapias tradicionales, que no proporcionan una recuperación total. Se han descrito la médula ósea y el tejido adiposo como fuentes principales de extracción de células madre. Ambos conllevan un proceso distinto de concentración celular que finalmente termina como un producto que debe ser inyectado en el tendón afectado y, dadas las características típicas de lesión núcleo presentadas en el tejido dañado, puede ser depositado en el centro de éste. El resultado esperado es la regeneración del tendón, sin exceso de tejido fibroso, observando alineación de las fibras tendíneas, disminución de la infiltración inflamatoria y zona hemorrágica. Con un programa de rehabilitación que incluya reposo y ejercicio progresivo, el equino vuelve a su estado competitivo óptimo. La factibilidad de realizar esta terapia en nuestra ubicación geográfica es posible, ya que la técnica de extracción desde ambas fuentes es simple y dentro de las opciones de concentración celular, siendo la del tejido adiposo más sencilla ya que requiere menos elementos y menor tiempo, ejecutándose la terapia en la etapa aguda de la lesión. La utilización de células madre en equinos es un tema de investigación creciente, que promete resultados alentadores.
\end{abstract}

Key words: tendonitis, mesenchymal stem cells, autologous, equine.

Palabras clave: tendinitis, células madre mesenquimales, autólogo, equino.

\section{INTRODUCTION}

Horse owners, veterinarians, and the equine industry in general are constantly searching for new and more effective treatments for injured horses (Yingling and Nobert 2008). Injuries during athletic activity are generally due to the cumulative effects of exercise and degenerative agerelated changes that have not been repaired by fibrocytes (Patterson-Kane and Firth 2009). These cells are highly differentiated that have limited potential for replication (Violini et al 2009). Tendons not only endure mechanical stress but also they are poorly vascularized, and the metacarpal SDFT (Superficial Digital Flexor Tendon) has a smaller cross-sectional area in its central region, which also may contribute to its susceptibility to injuries (Patterson-Kane and Firth 2009).

Of all sporting horses, polo horses are more to exposed to injuries in the metacarpal phalangeal joint, tendons and the ligamentous structures of the palmar region. The game of polo has an emphasis on speed, violent turns and sudden stops that make this activity very demanding (Tuemmers and Moran 2005). Sports statistics indicate that tendinitis is the most common cause of fractures, which are often career-ending for a Thoroughbred (Nixon et al 2008).

\footnotetext{
Accepted: 05.01.2012.

\# Directorate General for Research and Graduate Studies, Catholic University of Temuco, Internal Project 2009-3-09.

* Rudecindo Ortega 02990, Temuco, Chile; ctuemmers@uct.cl
}

The injuries in horses are broadly classified as resulting from extrinsic or intrinsic damage. Extrinsic injury is frequently associated with a sharp laceration or a traumatic blow that physically damages the ECM and/or cells. Intrinsic damage is associated with a degenerative condition within the tendon or ligament proper (Dahlgren, 2007). After a rupture, overlapping phases of reactivation of inflammation, proliferation, remodeling and maturation do not necessarily regenerate normal structure and function, which results in long-term persistence of scar tissue and a high incidence of new lesions (Patterson-Kane and Firth, 2009, Herthel, 2001). The stress on the injured tendon, induced by athletic endeavors in both horses and humans, often inhibits the return to previous activity levels (Violini et al 2009). In addition, the recurrence of tendinitis after returning to competition can be up to 43\% (Dyson 1997).

Decades of experience have demonstrated in vivo that tendon and ligament regeneration and repair are slow and inefficient after injury (Violini et al 2009). Bi et al (2007) affirmed that the repair of injured tendons remains as a considerable challenge, mostly due to the lack of knowledge in the characterization of tendon cells and their precursors.

Cell therapy is one of the most recent approaches to regenerative medicine, where this therapy aims to replace or repair damaged organs and tissues (Ferrari et al 2007). Mesenchymal stem cells (MSCs) have been investigated recently for their potential for use in regenerative medicine (Violini et al 2009). Multipotent stem cells are the precursors of specialized cells in specific 
tissues (Zaidi and Nixon 2007). Adult stem cells treated with specific factors represent a promising method for the use of tenocytes developed in vitro for tendon healing (Violini et al 2009).

MSCs appear to be a promising tool for cell therapy because of the characteristics they share with embryonic stem cells, in addition to advantages in terms of availability, scalability, transplantability and ethical implications (Krampera et al 2006, Murphy et al 2003). In the United States, the discussion of stem cell therapy is currently overshadowed by the ongoing political debate over embryonic stem cell research, as it was initially thought that embryos were the only viable source of stem cells (Yingling and Nobert 2008). In Latin America, understanding of the processes related to cell therapy and of MSC biology is still in the early stages (Pineda and Londoño 2009). The aim of this study is to describe the features, techniques for extraction, processing, application and effects of the stem cells therapy in tendon injuries in sportive horses.

\section{CELL THERAPY: MESENCHYMAL STEM CELLS}

Research on the use of MSCs in tissue regeneration has generally been driven by the needs of human medicine; however, the nature, prevalence and prognosis of superficial digital flexor tendinitis have placed equine veterinary science at the forefront of tendon regeneration research (Taylor et al 2007). MSCs derived from adult tissues have emerged as a potential injectable multipotent cell treatment. Under this treatment paradigm, the injected cells would have the capacity to differentiate and participate in the repair of various musculoskeletal tissues, including tendons. The long-term viability of these cells in tissue would yield lasting effects (Zaidi and Nixon 2007, Zuk et al 2002, Taléns-Visconti et al 2006, Hildebrand et al 2002).

The term "MSC" encompasses several heterogeneous groups of migratory cells in the body. All of these are cells that have left their original stem cell clusters and thus belong to a large pool of transitional cells that have the ability to renew themselves after trauma, disease or aging (Kruegel et al 2008, Pittenger et al 1999). Tissue injury that causes changes in the microenvironment may be one signal that induces stem cells intrinsic to the injured tissue to replace the existing necrotic cells (Bianchi Di Risio et al 2004).

The old belief that stem cell differentiation into a particular lineage is limited to the organ in which the cells are found has been replaced by evidence that MSCs are endowed with great plasticity that allows them to differentiate into a variety of tissues (Bianchi Di Risio et al 2004). These tissues include bone, cartilage, muscle, ligaments, tendons, adipose tissue and bone marrow stroma (Hildebrand et al 2002).

From the point of view of their reproductive capacity and function, MSCs have been defined as those that can divide for the purpose of self-renewal, producing more MSC like them, but also generate daughter cells committed to different cell lineages of functionally and morphologically specialized cells (Hernández and Dorticós 2004).

In adults, there are multipotent cells that originate from numerous mesenchymal tissues, such as bone marrow, perivascular tissue, blood, tendon, muscle and adipose tissue, any of which may potentially be used as a source of autogenous multipotent cells for transplantation (Bi et al 2007). However, according to Vidal et al (2006), a greater quantity of MSCs can be obtained in young animals.

Stem cells derived from adult tissues may participate in the regeneration of damaged tissue via two different mechanisms: the direct mechanism, which involves the phenotypic differentiation of tissue-specific cells, and the indirect mechanism, which involves the generation of tissue-specific extracellular matrix products (paracrin effect) (Nixon et al 2008). Differentiation and self-renewal of stem cells are regulated by specific cells in their environment (Bi et al 2007). Furthermore, according to Agung et al (2006), MSCs are able to move to the site of injury and contribute to tissue regeneration. Therefore, the use of autologous cells has an added benefit, as it does not incite a host immune response (Hildebrand et al 2002). These cells have been described as immunoregulatory or immunoprivilegiate because they are able to escape immune recognition and inhibit host defense mechanisms (Vinatier et al 2009, Tyndall and Uccelli 2009).

The above mentioned characteristic is the reason why the digital flexor tendon injuries in horses have an etiopathogeneses that differ from those of laceration injuries, but are ideal for the implementation of MSC therapy, as they provide a core within the lesion that can maintain implanted MSCs without the need for external support (Smith 2004).

However, regardless of the type of treatment selected, extended rest, with gradual increase of controlled exercise, is the cornerstone of successful recovery (Nixon et al 2008). It is observed that, the exercise can increase the capacity of tenocytes to repair microdamage (Kasashima et al 2007).

\section{CHARACTERISTICS OF STEM CELLS}

\section{ORIGIN AND POTENTIAL}

During early embryonic development, some of the embryonic stem cells from the inner cell mass of the blastocyst develop into mesoderm (Kruegel et al 2008, Koch et al 2008). These cells are progenitors of the adult mesenchymal cells that make up connective tissues such as bones, tendons, muscle and cartilage. Some of these embryonic mesenchymal cells are believed remain multipotent in each tissue (Kruegel et al 2008).

The biological property that best characterizes MSCs is their unique capacity to differentiate into osteoblasts, adipocytes and chondroblasts under standard differentiation culture conditions for tissues in vitro (Dominici et al 2006, Schnabel et al 2009). In the body, MSCs are able 
to self-renew and differentiate in a multipotent manner, depending on the precise regulatory conditions present in that area (Wang et al 2009).

Tenocytes are fibroblast cells responsible for matrix synthesis; it is thought that the stimulus for the differentiation of MSCs into tenocytes is a combination of mechanical tension, metabolic signals and contact with the surrounding cells and matrix (Patterson-Kane and Firth 2009, Smith 2004). MSCs produce and adhere to extracellular matrix molecules (Conget and Minguell 1999). Krampera et al (2006) found that upon injection of intravenous MSCs, the cells diffuse into all tissues, but preferentially survive and proliferate in the presence of regenerating tissues and tumors, where the MSCs develop into vascular-stromal fibroblasts.

\section{STEM CELL MORPHOLOGY}

MSCs are characterized by a spindle morphology, an elongated, central nucleus containing 2-3 small nucleoli $(<6 \mathrm{~mm})$ and primitive, unorganized euchromatin. (Flores et al 2006, Vidal et al 2006, Ratajczak et al 2008, Violini et al 2009).

In culture, MSCs have a population doubling time of 33 hours, a strong proliferative potential and a variety of distinctive cell cycle characteristics, including a subset (20\%) of cells that remain quiescent (inactive); these cells maintain a steady supply of cells which, via proliferation and delivery, can serve as precursors to a number of nonhematopoietic tissues (Conget and Minguell 1999).

\section{SOURCES OF STEM CELLS}

Several studies have isolated non-hematopoietic cells from bone marrow and cultured them in vitro, calling them "mesenchymal" cells because of their similarity to the mesenchymal tissue of the embryo, where these cells can be induced to form cell lines that will differentiate into new tissues (Bianchi Di Risio et al 2004, Baghavan et al 2009).

Adipose tissue contains a stromal vascular fraction (SVF), which is an accessible and abundant source of MSCs for cell therapy applications, such as tissue repair (Oedayrajsingh et al 2007, Taléns-Visconti et al 2006). Vidal et al (2007) described for the use of adipose tissue derived MSCs in tissue engineering for equine veterinary medicine.

It has been demonstrated that human and mouse tendons house a population of cells called tendon stem/ progenitor cells (TSPCs), which possess universal stem cell characteristics such as clonogenicity, multipotency and self-renewal capacity (Bi et al 2007).

\section{CELL SURFACE MARKERS OF STEM CELLS}

Interactions between cell surface receptors and their ligands are essential for cell attachment, communication and function (Majumdar et al 2002). Thus, surface phenotype, in conjunction with other functional criteria, can be used to better identify MSCs (Dominici et al 2006).

MSCs express CD13, CD29, CD44, CD71, CD90, CD105/SH2 (endoglin) and SH3 (Zuk et al 2002, De Mattos et al 2009). MSCs display an immunophenotype that is negative for the hematopoietic and endothelial markers CD14, CD34, CD45, CD31, vWF and HLA II (Zhang et al 2009). HLA-DR molecules are not expressed in MSCs unless the cells are stimulated to express them, as by IFN- $\gamma$ (Dominici et al 2006). Anderssen et al 2001, reported that stem cell they used in their research, are immunoreactive for nestin.

The discovery that MSCs from equine bone marrow express Oct4, Sox-2 and Nanog could indicate that the distinction between embryonic and adult markers is not as strict as originally thought, and that adult MSCs may also have the capacity to differentiate into tenocytes (Violini et al 2009, Zhang et al 2009).

After exposure of bone marrow MSCs to BMP-12, the MSCs expressed two tendon cell surface markers: tenomodulin and decorin (Violini et al 2009). TSPC (tendon stem/progenitors cells) express factors closely related to the tendon, such as SCX, TNMD, Comp and tenascin C (Bi et al 2007).

\section{FEATURES OF THE ADIPOSE TISSUE AS A SOURCE OF MSCS}

Adipose tissue is a complex mixture of cells, consisting of adipocytes, fibroblasts, vascular smooth muscle cells, endothelial cells and immune cells, as well as stem cells (TaPp et al 2008, Rehman et al 2004). Adipose tissue represents an accessible source of mesenchymal stem cells with characteristics similar to those of stem cells derived from bone marrow (Taléns-Visconti et al 2006, Zuk et al 2002). Moreover, Vidal et al (2007) argue that adipose tissue is a potential source of adult stem cells for use in tissue engineering for applications in equine regenerative medicine.

Stem cells derived from adipose tissue can readily be made available in large quantities. Minimal morbidity and discomfort are associated with harvesting the cells (Zuk et al 2001). Coccygeal fat at the base of the tail represents the most accessible site in horses with strong muscles, and it can be surgically removed using sedatives and local anesthesia (Nixon et al 2008).

Adipose-derived autologous stem cells (ASC) can be isolated relatively rapidly from adipose tissue via collagenase digestion (Vidal et al 2007). These harvested autologous cells are immunocompatible with the patient, and there are no ethical problems associated with their use, as the use of embryionic stem cells (Zuk et al 2001). The isolation of the fraction of nucleated cells from fat provides a pool of cells for immediate injection into lesion sites or for future use in propagation culture, where they can be 
maintained as a reserve of adipose-derived nucleated cells (Nixon et al 2008).

The performance of adipose cells can be influenced by age and tissue collection site (Vidal et al 2007, Colleoni et al 2009). The yield of nucleated cells derived from adipose tissue ranged from $1.47 \times 10^{6}$ cells $/ g$ to $2.71 \times 10^{6}$ cells $/ g$ (mean $\pm \mathrm{SD}, 2.30 \pm 0.57 \times 10^{6}$ cells $/ g$ ) (Nixon $e t$ al 2008). In the case of liposuction, yields are generally between 50 and $400 \times 10^{6}$ cells, which can be amplified at least 10-fold within 1 week (Rehman et al 2004). The viability of cells after digestion ranged from $83 \%$ to $91 \%$ (mean, 87.5\%) (Nixon et al 2008).

Nixon et al (2008) injected adipose-derived nucleated cell fractions and observed no adverse effects resulting from the injection. The range of time from the collection of adipose tissue to the injection of adipose-derived nucleated cells ranged from 40 to 53 hours. The mean \pm SD (standard deviation) number of adipose-derived nucleated cell fractions derived from adipose tissue in each syringe was $13.83 \pm 3.41 \times 10^{6}$ cells. On the basis of these data, adipose tissue may represent a source of stem cells that could have important consequences in several fields (Zuk et al 2002).

It is possible that the stem cells derived from adult tissues indirectly contribute to recovery by producing bioactive proteins such as growth factors, anti-apoptotic factors and chemotactic agents (Rehman et al 2004). These hidden proteins have important effects on local cell dynamics, stimulating vascular ingrowth and the recruitment of additional stem cells capable of stimulating recovery (Nixon et al 2008, Rehman et al 2004). Additionally, one of the most important adipocytokines produced by adipocytes is adiponectin, which has anti-inflammatory effects on endothelial cells; adiponectin inhibits the TNF induced by the expression of adhesion molecules, and interferes with the macrophage phagocytic function (Tilg and Moschen 2006).

Kisiday et al (2007) argued that adipose-derived cells have high rates of synthesis of extracellular matrix by wet weight, which is four times that of cell aggregation. These results suggested a repair potential per cell that is significantly lower than that of the MSCs derived from bone marrow, notwithstanding that the described study was performed to repair cartilage.

\section{MESENCHYMAL STEM CELLS FROM BONE MARROW}

Bone marrow is a complex, sinusoidal and wellorganized tissue located in the marrow cavity of the long bones, sternum, hip bones and spongy vertebrae, making it one of the major tissues of the body. Its main function is to promote hematopoiesis (Di Risio Bianchi et al 2004). In the complex cellular structure found in the bone marrow stroma, there is a subset of non-hematopoietic cells commonly referred to as bone marrow MSCs, which exhibit
98\% morphological uniformity in culture (Conget and Minguell 1999, Bianchi Di Risio et al 2004).

MSCs can be isolated from bone marrow and reproduced more than 1 billion-fold in cell culture, and gene transcripts can be harvested without affecting their differentiation potential (Hildebrand et al 2002, Baghavan et al 2009). Most clinical trials that have used bone marrow cells, however, report that the cells are available only in limited quantities and cannot be easily amplified (Rehman et al 2004).

It has been shown that equine bone marrow-derived MSCs play a central role in the repair and regeneration of mesenchymal tissues, and thus that they may be induced to differentiate into tenocytes (Violini et al 2009, Hankemeier et al 2005). Without specific differential induction, however, therapeutic use of these cells could potentially lead to ossification, exacerbating the tendinopathy (Bi et al 2007). Other potential drawbacks in the use of bone marrow aspirates to provide a pool of MSCs for therapeutic purposes include the pain associated with the collection process, low cell yield and pneumothorax and pericardial lacerations during bone marrow harvest from the sternum (Nixon et al 2008, Zuk et al 2001, Vidal et al 2007). Thus, the clinical use of bone marrow-derived stem cells may be harmful to the donor due to the highly invasive collection procedure. Furthermore, bone marrow aspirates may contain few stem cells (Kern et al 2006, Wang et al 2009, Nixon et al 2008).

From a practical standpoint, the low number of stem cells harvested necessitates an ex vivo expansion stage to obtain a clinically significant number of cells. This step is slow and expensive, and it risks contamination of the line and loss of cells (Zuk et al 2001). Pittenger et al (1999), however, obtained positive results after 1-3 weeks in lineage-specific culture media without evidence of other lines in the culture.

In bone marrow, adult stem cells are found at a prevalence of 1 stem cell in 100,000 bone marrow nucleated cells (Zaidi and Nixon 2007). The separation of bone marrow aspirates collected from adult horses resulted in a harvest of $6.4 \pm 3.4 \times 10^{6}$ nucleated cells/ $\mathrm{ml}$ of aspirate. Cell viability after thawing of primary colt MSCs stored in liquid nitrogen of was $64 \pm 6 \%$ (Vidal et al 2006).

\section{TECHNIQUES FOR EXTRACTION, PROCESSING AND APPLICATION OF NUCLEATED CELL FRACTIONS}

\section{PRIMARY SOURCE: ADIPOSE TISSUE}

Step 1: Aseptic cleaning, patient sedation and desensitization of the area. Vidal et al (2007) suggest that horses should be sedated with detomidine $\mathrm{HCl}(0.04 \mathrm{mg} / \mathrm{kg}$ intravenous [IV]) and butorphanol (0.01 mg/kg IV), that the area along the dorsal gluteal muscle and skin with 


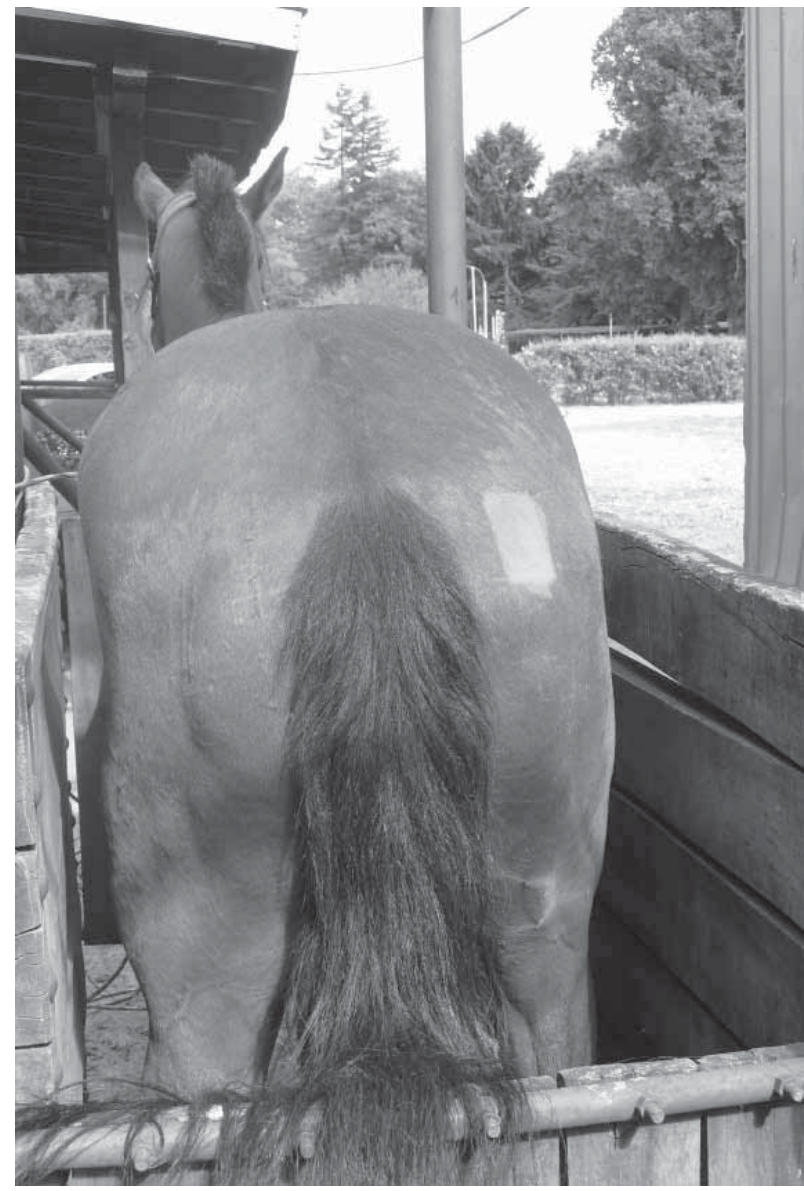

Figure 1: Site of extraction of adipose tissue. Sitio de extracción de tejido adiposo.

subcutaneous tissue should be prepared aseptically , and that the area should be numbed with local application of lidocaine $2 \%$, using an inverted L block.

\section{Step 2: Harvest of adipose tissue.}

A) Surgical extraction: The paraxial caudodorsal gluteal region is opened (Nixon et al 2008). Subcutaneous adipose tissue is collected from above the dorsal region of the gluteal muscle (Vidal et al 2007). A linear incision $10-15 \mathrm{~cm}$ long is made from about $10 \mathrm{~cm}$ abaxial to the vertebral column and $10 \mathrm{~cm}$ cranial to the tail head; the incision should be centered in the groove formed by the proximal origin of the biceps femoris and semitendinosus. About 15-20 g of subcutaneous adipose tissue is then dissected using curved scissors. Next, the skin incision is closed with 0 polypropylene, using a simple interrupted suture pattern or a Ford interlocking pattern. It is recommended to provide NSAIDs for 3 days after harvesting the adipose tissue (Nixon et al 2008).

B) Alternative collection method: liposuction. Method as described in humans. In this procedure, a hollow blunt cannula is introduced into the subcutaneous space through small incisions $(1 \mathrm{~cm})$. The cannula is connected to gentle suction and moved through the adipose compartment, mechanically disrupting the fat tissue. A saline solution and epinephrine (as a vasoconstrictor) are infused into the fat compartment to minimize blood loss and tissue contamination by peripheral blood cells (Zuk et al 2001).

\section{Step 3: Fat sample processing.}

A) Procedure from surgical extraction. The adipose tissue sample is placed in a $50-\mathrm{mL}$ falcon tube containing sterile phosphate-buffered saline solution (PBS) and maintained at $4{ }^{\circ} \mathrm{C}$ (Nixon et al 2008). The sample is ground with a surgical blade, washed and briefly stirred with an equal volume of buffer solution (PBS) to promote the separation into 2 phases. The upper phase consists of ground and washed adipose tissue, and the infranatant fluid contains hematopoietic cells suspended in PBS. This fluid is removed (Vidal et al 2007).

The tissue is then digested in an equal volume of filtered PBS solution containing 1\% bovine serum albumin and $0.1 \%$ collagenase type I, with continuous stirring at $37^{\circ} \mathrm{C}$ for 50 minutes (Vidal et al 2007). Subsequently, suspensions are filtered with $500 \mu \mathrm{m}$ and $250 \mu \mathrm{m}$ Nitex (Rehman et al 2004). To complete the separation of the stromal cells from the primary adipocytes, the sample is briefly and vigorously stirred, then centrifuged at $260 \mathrm{x} \mathrm{g}$ for 5 minutes, resulting in an SFV pellet containing nucleated cells and an adipose tissue fraction, which can be discarded. The stem cells can then be harvested (Awad et al 2003, Danišovič et al 2007, Vidal et al 2007).

The SFB pellet is resuspended in $160 \mathrm{~mm} \mathrm{NH}_{4} \mathrm{Cl}$ and incubated at room temperature for 10 minutes to lyse the blood cells, and the solution is centrifuged at $300 \mathrm{~g}$ for 5 minutes, resulting in an injectable product (Nixon et al 2008, Rehman et al 2004, Taléns-Visconti et al 2006).

Step 4: Application of adipose-derived nucleated cell fractions in tendon. After isolation and purification, the adipose-derived nucleated cell fractions pellet derived from adipose tissue is resuspended in $0.6-\mathrm{mL}$ aliquots of sterile PBS solution and loaded into 3 sterile syringes labeled with the data and ID of the donor horse. Then, clip the leg to be implanted to include subcarpal local anaesthetic sites. Subsequently, the upper middle metacarpal area of the each horse's injured tendon is prepared for aseptic injection with three 22-gauge needles. Using ultrasound guidance to give a side view of the SDFT ensures the entry of the needle into the center of the lesion. The needles are placed approximately $1 \mathrm{~cm}$ apart, beginning $15 \mathrm{~cm}$ distal to the accessory carpal bone and moving progressively distally. A sterile dressing is then applied (Nixon et al 2008). 


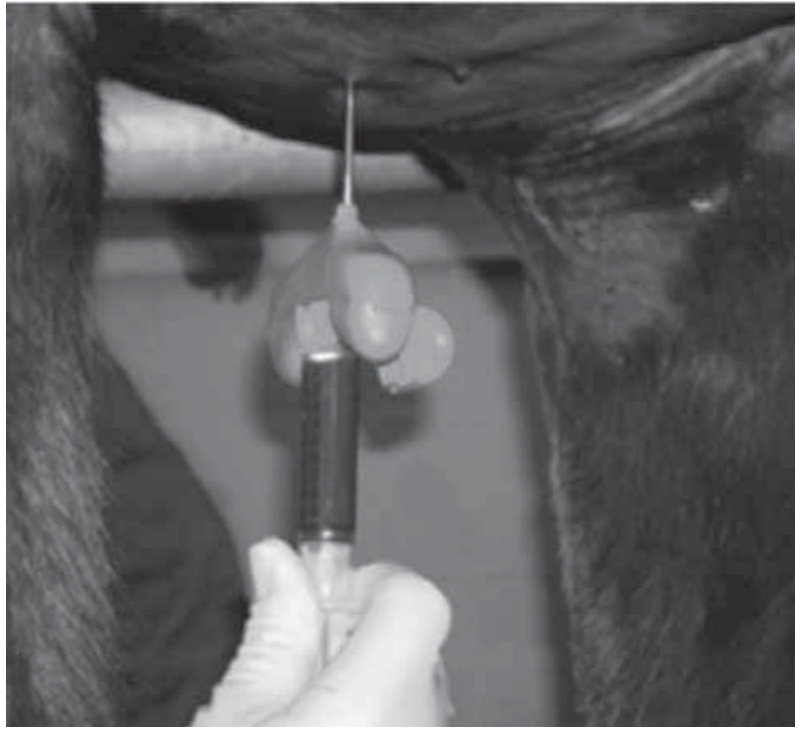

Figure 2: Aspiration of bone marrow technique from the sternum (Kasashima et al 2011).

Técnica de aspiración de medula ósea desde esternón. (Kasashima et al 2011).

\section{SECONDARY SOURCE: BONE MARROW}

Step 1: Cleaning and patient sedation. The collection is prepared aseptically. Violini et al (2009) aseptically obtained samples of bone marrow (BM) from the sternum, maintaining general anesthesia during surgery, and Pacini et al (2007) obtained bone marrow aspirates via sternal puncture under local anesthesia with a subcutaneous injection of $5 \mathrm{ml}$ of lidocaine (2\%).

Step 2: Bone marrow harvesting and surgical extraction. Intersternebral spaces are easily identified via ultrasound. Bone marrow needles are used for marrow aspiration into two 20-mL syringes containing 30,000 units each of sodium heparin. Immediately after collection, samples are stored on ice (Violini et al 2009). Kasashima et al 2011, suggests that the most practical and safest site to aspirate bone marrow is from the $5^{\text {th }}$ sternebra, as it is sufficiently caudal to avoid the cranial ventral bony crest, which covers the first 3 sternebrae and is easily accessible and identifiable.

Step 3: Sample processing. The bone marrow sample (30 $\mathrm{mL}$ ) is placed in a Hystopaque TM 1077 (Sigma Aldrich, St. Louis, MO) tube and centrifuged for 20 minutes at 400 $\mathrm{g}$ at $4{ }^{\circ} \mathrm{C}$. The supernatant MSC-enriched cell population is aspirated and then washed in magnesium- and calciumfree PBS, then centrifuged at $260 \mathrm{~g}$ for $5 \mathrm{~min}$ at $4{ }^{\circ} \mathrm{C}$. The cell pellet is then resuspended in $10 \mathrm{ml}$ of Dulbecco's Modified Eagle Medium (DMEM) supplemented with $10 \%$ fetal calf serum (FCS), penicillin $(100 \mathrm{U} / \mathrm{ml})$ and streptomycin $(100 \mu \mathrm{g} / \mathrm{ml})(\mathrm{P} / \mathrm{S})$ and $1 \%$ nonessential amino acids. Next, the cells are seeded in 24 -well plates
(Violini et al 2009). The medium, containing $50 \mathrm{ng} / \mathrm{mL}$ epidermal growth factor (EGF), is changed every 2-3 days, and non-adherent cells are removed (Violini et al 2009, Zhang et al 2009).

Step 4: Culture for amplification of stem cells. After 2 weeks, when cells are actively dividing, they are quantified and seeded in T25 flasks $\left(4 \times 10^{5}\right.$ cells/flask $)$ or 24 -well plates $\left(2 \times 10^{5}\right.$ cells $\left./ \mathrm{ml}\right)$ and incubated at $37^{\circ} \mathrm{C}$, with $5 \%$ $\mathrm{CO}_{2}$ (Violini et al 2009).

Step 5: Induction of differentiation. Although this step is not necessary, Violini et al (2009) suggest that when bone marrow-derived MSCs achieve $70 \%$ confluence, the cells should be trypsinized, counted and plated at a density of $6 \times 10^{5}$ in a culture flask T25. To induce differentiation into tenocytes, cell cultures are maintained for 14-21 days in culture medium supplemented with BMP-12 $50 \mathrm{ng} / \mathrm{mL}$.

Step 6: Therapeutic application. This step is similar to step 4 (described above) for adipose tissue.

\section{EXPECTED RESULTS OF ADIPOSE TISSUE- DERIVED NUCLEATED CELLS TREATMENT}

The tendons treated with adipose-derived nucleated cells, show significant clinical improvement, as indicated by the linearity and uniformity of the collagen fibers observed via ultrasound examination, the appearance of striations under polarized light microscopy, a reduction in the infiltration of WBCs (white blood cells), and no evidence of bleeding and a smoother surface on the epitenon. The expression of collagen type I show no obvious changes after treatment; however, the expression of collagen type III is evident in healed tendon and is reduced in tendons treated with adipose-derived nucleated cells. The expression of COMP (cartilage oligomeric matrix protein) is significantly increased in tendons treated with MSCs derived from adipose tissue (Nixon et al 2008).

\section{EXPECTED RESULTS OF TREATMENT WITH BONE MARROW-DERIVED MSCS}

Pacini et al (2007) observed that 9 out of 11 animals treated with MSCs achieved full recoveries, as shown by ultrasound images of the tendons taken after a period of 3-6 months, when they returned to racing. The horses even achieved competitive results in the same competitive tiers they had raced in prior to injury. Furthermore, the horses went 9-12 months without recurrence of injury, and 9 out of 10 showed increased density of the tendon, indicating the initial stages of repair after only 1 month. Six months after the injection of mesenchymal cells, the tendons appeared to be almost completely repaired. 
Lacitignola et al (2008) conducted a study on cell therapy for tendinitis in horses with collagenase-induced tendinitis. In this study, the transplantation of MSCs derived from bone marrow produced regeneration of the extracellular matrix of tendons by enhancing the rates of production of collagen type I/III, and expression of COMP and improving fiber orientation. In parallel, the same authors conducted a clinical study to verify the clinical efficacy of autologous grafting of MSCs derived from bone marrow into spontaneous lesions (resulting from excessive tension) of ligaments and tendons in horses. The subjects were observed for a minimum of 16 weeks and a maximum of 150 weeks after treatment, with an average of 48 weeks of follow-up observation. All animals exhibited the same result: there was no swelling or inflammatory response after implantation of MSCs derived bone-marrow. Three weeks after treatment, researchers found no pain in response to digital pressure at the site of injury. At 6 weeks, and through subsequent follow-ups, no lameness was evident upon clinical examination. The lesions began to improve after 3 weeks. CSA-L (cross sectional area of the lesion), FPS (fiber pattern score) and TLS (type lesion score) improved in all patients, with an appreciable filling-in of the lesions, indicated by a decrease in the CSA-1 and an increase in TLS. This trend remained consistent through subsequent follow-ups. When the horses started the exercise program, the tendon architecture, as measured by its length and longitudinal alignment, also improved. At the time of reporting, 12 subjects (60\%) had returned to racing and 8 $(40 \%)$ were training under a controlled exercise program. It was observed a recurrence of injury of $35 \%$, and all owners rated the outcome (in terms of sporting success) from good to excellent (Lacitignola et al 2008).

\section{CONCLUSION}

It is relevant to emphazise this therapy as an interesting, effective and efficient method which in fact has not been intensively developed in our country yet. Different sources of stem cell extraction, mainly bone marrow and adipose tissue, from the same patient in question could be used for the treatment of tendons in sport horses. They can present certain advantages and disadvantages over other sources, mainly due to the number of nucleated cells which is higher in adipose tissue while the extraction of bone marrow could be a very invasive process.

It is suggested to expand and to polish the procedure by incorporating protocol, identification of extracted cell contents, filtered and purified, as well as to make cell amplification and application of diverse pathological conditions that require tissue regeneration.

Therefore, regenerative therapy is presented as a therapeutic tool that can provide a solution to the constant concern of breeders, veterinarians and owners of sport horses regarding frequent locomotor problems of their animals, such as tendinitis.

\section{SUMMARY}

Finding a cure for tendonitis in sporting horses has been a challenge for veterinarians during a long time. Regenerative medicine using stem cells from the patient has emerged as an innovative method that allows breaking the barriers of finding a resolution that can be maintained over time. Additionally, the benefits surpass those of traditional therapies, which do not facilitate full recovery. Bone marrow and adipose tissue have been described as major sources for stem cell extraction. The use of both tissues involves different processes of cell harvesting and concentration, which eventually yield a product that must be injected into the affected region, or in the center of a typical core lesion. The expected result is the regeneration of the tendon without excess fibrous tissue, properly aligned tendon fibers and decreased inflammatory infiltration and hemorrhage. Following a rehabilitation program that includes resting and progressive exercise, the horse returns to its previous competitive condition. This therapy is feasible because the techniques for extraction from both sources are simple. If the two techniques are compared, adipose tissue extraction is easier because it requires fewer elements and less time. Both therapies, however, can be executed in the acute stage of injury. The use of stem cells in horses is the subject of a growing body research that has already yielded encouraging results.

\section{REFERENCES}

Agung M, M Ochi, S Yanada, N Adachi, Y Izuta, T Yamasaki, K Toda. 2006. Mobilization of bone marrow-derived mesenchymal stem cells into the injured tissues after intraarticular injection and their contribution to tissue regeneration. Knee Surg Sport Tr A 14, 1307-1314.

Anderssen C, E Stocker, F Klinz, N Lenka. 2001. Nestin-Specific Green Fluorescent Protein Expression in Embryonic Stem Cell-Derived Neural Precursor Cells Used for Transplantation. Stem cells 19, 419-424.

Awad H, M Wickham, H Leddy, J Gimble, F Guilak. 2003. Chondrogenic differentiation of adipose-derived adult stem cells in agarose, alginate, and gelatin scaffolds. Biomaterials 25, 3211-3222.

Baghavan M, L Taghiyar, M Dehghan, F Fallahi, H Kazemi. 2009. Equine marrow-derived mesenchymal stem cells: isolation, differentiation and culture optimization. Iran J Vet Res 10, 1-26.

Bi Y, D Ehirchiou, T Kilts, C Inkson, M Embree, W Sonoyama, L Li, A Leet, B Seo, L Zhang, S Shi, M Young. 2007. Identification of tendon stem/progenitor cells and the role of the extracellular matrix in their niche. Nat Med 13, 1219-1227.

Bianchi Di Risio C, F Callero, A Hidalgo, P Argibay. 2004. Células mesenquimales de médula ósea, diferenciación y potencial reemplazo neuronal. Medicina (Buenos Aires) 64, 543-549.

Colleoni S, E Bottani, I Tessaro, G Mari, B Merlo, N Romagnoli, A Spadari, C Galli, G Lazzari. 2009. Isolation, growth and differentiation of equine mesenchymal stem cells: effect of donor, source, amount of tissue and supplementation with basic fibroblast growth factor. Vet Res Commun 33, 811-821.

Conget P, J Minguell. 1999. Phenotypical and functional properties of human bone marrow mesenchymal progenitor cells. J Cell Physiol 181, 67-73.

Dahlgren L. 2007. Pathobiology of tendon and ligament injuries. Clin Tech Equine Pract 6, 168-173.

Danišovič L, P Lesný, V Havlas, P Teyssler, Z Syrová1, M Kopáni, G Fujeríková, T Trč, E Syková, P Jendelová. 2007. Chondrogenic differentiation of human bone marrow and adipose tissue-derived mesenchymal stem cells. J Appl Biomed 5, 139-150.

De Mattos A, A Garcia, M Assis, A Moroz, C Hussni, P Galvao, E Deffune. 2009. Isolation and immunophenotypic characterization of mesenchymal stem cells derived from equine species adipose tissue. Vet Immunol Immunopathol 132, 303-306.

Dominici M, K Le Blanc, I Mueller, I Slaper-Cortenbach, FC Marini, DS Krause, RJ Deans, A Keating, DJ Prockop, EM Horwitz. 2006. Minimal criteria for defining multipotent mesenchymal stromal cells. 
The International Society for Cellular Therapy position statement. Cytotherapy 8, 315-317.

Dyson S. 1997. Treatment of superficial digital flexor tendinitis: a comparison of conservative management, sodium hyaluronate, and glycosaminoglycan polysulfate. Proceedings $43^{\text {rd }}$ Ann Conv Am Assoc Equine Pract, 297-300.

Ferrari M, A Corradi, M Lazzaretti, M De Cilla, C Losi, R Villa, A Lanfranchi. 2007. Adult stem cells: perspectives for therapeutic applications. Vet Res Commun 31, 1-8.

Flores E, J Montesinos, H Mayani. 2006. Células troncales mesenquimales: historia, biología y aplicación clínica. Rev Invest Clin 58, 498-511.

Gillis C. 1996. Tendon and ligament rehabilitation in proceedings. Dubai Int Equine Symp 417-421.

Godoy A, I Oddoy. 1995. Diagnóstico ultrasonográfico de la patología de tendones y ligamentos en el equino de deporte. Monogr Med Vet 17, 1-2.

Hankemeier S, M Keus, J Zeichen, M Jagodzinski, T Barkhausen, U Bosch, C Krettek, M Van Griensven. 2005. Modulation of proliferation and differentiation of human bone marrow stromal cells by fibroblast growth factor 2: potential implications for tissue engineering of tendons and ligaments. Tissue Eng 11, 41-49.

Hernández P, E Dorticós. 2004. Medicina regenerativa. Células madre embrionarias y adultas. Rev Cub Hematol Immunol Hemoter 20, 3 .

Herthel D. 2001. Enhanced suspensory ligament healing in 100 horses by stem cells and other bone marrow components. Abstract 47th AAEP Annual Convention, USA, 319-321.

Hildebrand K, F Jia, S Woo. 2002. Response of donor and recipient cells alter transplantation of cells to the ligament and tendon. Microsc Res Techniq 58, 34-38.

Kasashima Y, T Takahashi, H Birch, R Smith, A Goodship. 2007. Can exercise modulate the maturation of functionally different immature tendons in the horse? J Appl Physiol 104, 416-422.

KasashimaY, T Ueno, A Tomita, E Goodship, K Smith. 2011. Optimisation of bone marrow aspiration from the equine sternum for the safe recovery of mesenchymal stem cells. Equine Vet J 43, 288-294.

Kern S, H Eichler, J Stoeve, H Klüter, K Bieback. 2006. Comparative analysis of mesenchymal stem cells from bone marrow, umbilical cord blood or adipose tissue. Tissue-specific stem cells. Alpha Med Press 1-35.

Kisiday J, P Kopesky, C Evans, A Grodzinsky, W McIlwraith, D Frisbie. 2007. Evaluation of adult equine bone marrow- and adiposederived progenitor cell chondrogenesis in hydrogel cultures. Wiley InterScience 26, 322-331.

Koch T, L Berg, D Betts. 2008. Concepts for the clinical use of stem cells in equine medicine. Can Vet J 49, 1009-1017.

Krampera M, G Pizzolo, G Aprili, M Franchini. 2006. Mesenchymal stem cells for bone, cartilage, tendon and skeletal muscle repair. Bone 39, 678-683.

Kruegel J, N Miosge, S Koelling. 2008. The role of progenitor cells in osteoarthritis. Curr Rheumatol Rev 4, 210-213.

Lacitignola L, A Crovace, G Rossi, E Francioso. 2008. Cell therapy for tendinitis, experimental and clinical report. Vet Res Commun 32, 33-38.

Majumdar M, M Keane-Moore, D Buyaner, W Ardí, M Moorman, K Mclntosh, J Mosca. 2002. Characterization and functionality of cell surface molecules on human mesenchymal stem cells. J Biomed Sci 10, 228-241.

Murphy J, D Fink, E Hunziker, F Barry. 2003. Stem cell therapy in a caprine model of osteoarthritis. Arthritis Rheum 48, 3464-3474.

Nixon A, L Dahlgren, J Haupt, A Yeager, D Ward. 2008. Effect of adipose-derived nucleated cell fractions on tendon repair in horses with collagenase-induced tendinitis. Am J Vet Res 69, 928-937.

Oedayrajsingh M, R Breuls, T Schouten, W Jurgens, H Bontkes, G Schuurhuis, S Marieke, F Van Milligen. 2007. Phenotypical and functional characterization of freshly isolated adipose tissue-derived stem cells. Stem Cells Dev 16, 91-104.

Pacini S, S Spinabella, L Trombi, R Fazzi, S Galimberti, F Dini, F Carlucci, M Petrini. 2007. Suspension of bone marrow-derived undifferentiated mesenchymal stromal cells for repair of superficial digital flexor tendon in race horses. Tissue Eng 13, 2949-2955.

Patterson-Kane J, E Firth. 2009. The pathobiology of exercise-induced superficial digital flexor tendon injury in Thoroughbred racehorses. Vet $J 181,79-89$.

Pineda C, C Londoño. 2009. Obtención de células madre del tejido adiposo y su potencial de diferenciación osteogénico. Rev Ing Bioméd 3, 58-65.

Pittenger M, A Mackay, S Beck, R Jaiswal, R Douglas, J Mosca, M Moorman, D Simonetti, S Craig, D Marshak. 1999. Multilineage potential of adult human mesenchymal stem cells. Science 284, 143.

Ratajczak M, M Kucia, J Ratajczak, E Zuba-Surma. 2008. A multiinstrumental approach to identify and purify very small embryonic like stem cells (VSELs) from adult tissues. Micron 40, 386-393.

Rehman J, D Traktuev, J Li, S Merfeld-Clauss, C Temm-Grove, J Bovenkerk, C Pell, B Johnstone, R Considine, K March. 2004. Secretion of angiogenic and antiapoptotic factors by human adipose stromal cells. Circulation 109, 1292-1298.

Schnabel L, M Lynch, M Van der Meulen, A Yeager, M Kornatowski, A Nixon. 2009. Mesenchymal stem cells and insulin-like growth factor-I gene- enhanced mesenchymal stem cells improve structural aspects of healing in equine flexor digitorum superficialis tendons. J Orthop Res 27, 1392-1398.

Smith R. 2004. Stem cell therapy for tendon and ligament injuries - Clinical results. Abstract 12th ESVOT Congress, Munich, Pp 187-188.

Taléns-Visconti R, A Bonora, R Jover, V Mirabet, F Carbonell, J Castell, M Gómez-Lechón. 2006. Human mesenchymal stem cells from adipose tissue: differentiation into hepatic lineage. Toxicol in vitro 21, 324-329.

Tapp H, E Hanley Jr., J Patt, H Gruber. 2008. Adipose-derived stem cells: characterization and current application in orthopaedic tissue repair. Exp Biol Med 1-9.

Taylor S, R Smith, P Clegg. 2007. Mesenchymal stem cell therapy in equine musculoskeletal disease: scientific fact or clinical fiction? Review article. Equine Vet J 39, 172-180.

Tilg H, A Moschen. 2006. Adipocytokines: mediators linking adipose tissue, inflammation and immunity. Nat Rev Immunol 6, 772-783.

Tuemmers C, G Morán. 2005. Hallazgos ultrasonográficos del tendón flexor digital superficial de la región del metacarpo en 40 equinos de polo. Arch Med Vet 37, 67-70.

Tyndall A, A Uccelli. 2009. Multipotent mesenchymal stromal cells for autoimmune diseases: teaching new dogs old tricks. Bone Marrow Transpl 43, 821-828.

Vidal M, G Kilroy, J Johnson, M López, R Moore, J Gimble. 2006. Cell growth characteristics and differentiation frequency of adherent equine bone marrow-derived mesenchymal stromal cells: adipogenic and osteogenic capacity. Vet Surg 35, 601-610.

Vidal M, G Kilroy, M López, J Johnson, R Moore, J Gimble. 2007. Characterization of equine adipose tissue-derived stromal cells: adipogenic and osteogenic capacity and comparison with bone marrow-derived mesenchymal stromal cells. Vet Surg 36, 613-622.

Vidal M, S Robinson, M López, D Paulsen, Olga Borkhsenious, J Johnson, R Moore, J Gimble. 2008. Comparison of chondrogenic potential in equine mesenchymal stromal cells derived from adipose tissue and bone marrow. Vet Surg 37, 713-724.

Vinatier C, D Mrugala, C Jorgensen, J Guicheux, D Noel. 2009. Cartilage engineering: a crucial combination of cells, biomaterials and biofactors. Trends Biotechnol 27, 307-314.

Violini S, P Ramelli, L Pisani, C Gorni, P Mariani. 2009. Horse bone marrow mesenchymal stem cells express embryo stem cell markers and show the ability for tenogenic differentiation by in vitro exposure to BMP-12. BMC Cell Biol 10, 29.

Wang W, K Itaka, S Ohba, N Nishiyama, U Chung, Y Yamasaki, K Kataoka. 2009. 3D spheroid culture system on micropatterned substrates for improved differentiation efficiency of multipotent mesenchymal stem cells. Biomaterials 30, 2705-2715. 
TENDONITIS, MESENCHYMAL STEM CELLS, AUTOLOGOUS, EQUINE

Yingling G, K Nobert. 2008. Regulatory considerations related to stem cell treatment in horses. J Am Vet Med Assoc 232, 1657-1661.

Zaidi N, A Nixon. 2007. Stem cell therapy in bone repair and regeneration. Ann N Y Acad Sci 1117, 62-72.

Zhang Z, S Teoh, W Chong, T Foo, Y Chng, M Choolani, J Chan. 2009. A biaxial rotating bioreactor for the culture of fetal mesenchymal stem cells for bone tissue engineering. Biomaterials 30, 2694-2704.
Zuk P, M Zhu, H Mizuno, J Huang, J Futrell, A Katz, P Benhaim, H Lorenz, M Hedrick. 2001. Multilineage cells from human adipose tissue: implications for cell-based therapies. Tissue Eng 7, 211-228.

Zuk P, M Zhu, P Ashjian, D Ugarte, J Huang, H Mizuno, Z Alfonso, J Fraser, P Benhaim, M Hedrick. 2002. Human adipose tissue is a source of multipotent stem cells. Mol Biol Cell 13, 4279-4295. 